\title{
GERABAH SITUS WAYPUTIH SEBAGAI KOMODITI BARTER DI KERAJAAN HOAMOAL
}

\section{The Pottery of Wayputih as The Exchange Commodity of Hoamoal Kingdom}

\author{
Wuri Handoko \\ Balai Arkeologi Ambon \\ J1. Namalatu Latuhalat \\ Email : wuri_balarambon@yahoo.com
}

Naskah diterima: 14-02-2013; direvisi: 08-03-2013; disetujui: 10-05-2013

\begin{abstract}
The site of Wayputih settlement in the history and traditions of the various sources mentioned as the part of the Kingdom Hoamoal region. This study aims to clarify the role of settlement Wayputih sites as the region as one of the central region of the kingdom Hoamoal clove producer. In addition it describes the process of trade and exchange between commodities produced by commodity from outside the area. This study uses a survey to see traces of settlements based on primary data pottery artifacts, then perform quantitative and qualitative analysis of data to explain the use and development of the system of commodity exchanges in the region. The results of the study, found the distribution of pottery with a high quantity in the site area. It can be concluded that based on the intensity of pottery and not produced in the local area, then to obtain it from outside the region to barter with cloves produced in the local area. Trade and exchange of pottery with cloves in Wayputih, support the development of trade in the territory of the Kingdom Hoamoal.
\end{abstract}

Keywords: Pottery, Cloves, Trade, Hoamoal

\begin{abstract}
Abstrak
Situs pemukiman Wayputih dalam berbagai sumber sejarah maupun tradisi tutur merupakan wilayah pemerintahan dari Kerajaan Hoamoal. Penelitian ini bertujuan untuk menjelaskan peranan permukiman situs Wayputih sebagai wilayah sebagai salah satu wilayah pusat penghasil cengkeh bagi kerajaan Hoamoal. Selain itu menggambarkan proses perdagangan dan pertukaran antara komoditi yang dihasilkan dengan komoditi dari luar wilayah. Penelitian ini menggunakan metode survei untuk melihat jejak-jejak permukiman berdasarkan data utama artefak gerabah, selanjutnya melakukan analisis secara kuantitatif dan kualitatif data untuk menjelaskan penggunaan dan perkembangan sistem pertukaran komoditi di wilayah tersebut. Hasil penelitian, ditemukan sebaran gerabah dengan kuantitas yang tinggi di wilayah situs tersebut. Dapat disimpulkan bahwa berdasarkan intensitas gerabah dan tidak dihasilkan di wilayah setempat, maka untuk memperolehnya dari wilayah luar dengan melakukan barter dengan cengkeh yang dihasilkan di wilayah setempat. Perdagangan dan pertukaran gerabah dengan cengkeh di Wayputih, mendukung perkembangan niaga di wilayah Kerajaan Hoamoal.
\end{abstract}

Kata Kunci : Gerabah, Cengkeh, Perdagangan, Hoamoal

\section{PENDAHULUAN}

Dalam berbagai sumber sejarah disebutkan bahwa Kerajaan Hoamoal adalah wilayah ekspansi dari kekuasaan Islam Ternate. Wilayah persebaran ini merupakan dampak dari persaingan antara dua kerajaan pusat kekuasan Islam di Maluku Utara, yakni Ternate dan Tidore. Ternate dan Tidore bersaing memperoleh legitimasi politik sebagai wilayah pusat kekuasaan Islam, 
sehingga masing-masing kerajaan bersaing untuk melebarkan sayap kekuasaannya. Ternate berekspansi ke wilayah Seram Bara yakni jazirah Hoamoal, di situ terdapa Kerajaan Hoamoal dan ke wilayah Pulau Ambon, sementara Tidore berekspansi ke wilayah pesisir utara Pulau Seram, Kepulauan Gorom dan Seram Laut di bagian timur pulau Seram, bahkan mencapai kepulauan Raja Empat, Irian. Peranan Ternate dan Tidore sebagai bandar jalur sutera dengan sendirinya terkait dengan ekspansi itu (Leirissa, 2001 $7-8)$.

Seiring dengan itu, perluasan agama Islam dari kedua kerajaan tersebut juga berjalan. Sejarah mencatat, Ternate dan Tidore adalah dua kerajaan di wilayah Maluku Utara yang dapat dipresentasikan sebagai wilayah pusat kekuasaan Islam di wilayah Maluku Utara. Ternate, melebarka sayap ke wilayah selatan Maluku, meliputi Pulau Ambon, Haruku, Saparua, Buru, Seram Bagian Barat dan Tengah. Sementara itu Tidore melebarkan sayap kekuasaannya ke wilayah pesisir utara Pulau Seram dan wilayah kepulauan di sisi paling timur Pulau Seram, yakni Gorom dan Seram Laut hingg ke wilayah Kepulauan Raja Ampat Irian Jaya (Leirissa, 2001:8). Dapat dianggap kedua wilayah kesultanan itu saling bersaing melebarkan sayap kekuasaannya hingg keluar wilayah geografisnya ke wilayah pulau-pulau diseberang lautan. Catatan lain yang mendukung bahwa wilayah Kerajaa Ternate, adalah be Ternate, adalah bahwa Ternate, menempatkan wakilnya yakni Gimelaha yang memerintah di wilayah-wilayah yang dikuasai Ternate di Maluku Tengah. Gimelaha Bassi sebagai wakil Ternate, berkedudukan di wilayah yang disebut Gamsugi, di pantai timur jazira Hoamoal, yakni kota pelabuhan Luhu sebagai Gimelaha kedua yang memerintah hingga 1612 (Leirissa, 1973: 48).

Dalam catatan sejarah dan sumber lisan, kekuasaan Gimelaha berawal dari tahu 1600-1656, yakni masa kemenangan VOC atas Portugis dimana saat itu Ternate bermitra dengan VOC, hingga masa jatuhnya Kerajaan am operasi Hongitochten, yakn menebang atau menebas seluruh kebun cengkeh di wilayah kerajaan Hoamoal. Hal ini berkaitan dengan keberhasilan Gubernur de Vlaming pada Januari 1652, untuk mendesak Sultan Ternate Mandar Syah menandatangani perjanjian tentang pelarangan penanaman pohon cengkeh di wilayah Maluku (dan Maluku Utara) kecuali di Pulau Ambon dan pulau-pulau kecil di sekitarnya. Kebijakan ini diikuti pula dengan pemusatan penanaman pohon pala di Kepulauan Banda (Ricklefs. M.C. 2008: 102)

Untuk menjamin pelaksanaan perjanjian ini, Belanda menerapkan kebijakan pelayaran hongi atau ekspedisi hongitochten. Pelayaran hongi atau armada hongi adalah pengerahan armada kapal yang dipersenjatai untuk melakukan pengawasan terhadap daerahdaerah penghasil cengkeh. Pelayaran hongi telah berlangsung sejak masa pendudukan Portugis dan sistem ini dilanjutkan oleh Belanda setelah berhasil merebut penguasaan atas wilayah ini. Sejak pemerintahan Portugis, telah berlangsung hubungan antara penduduk Leitimor (bagian timur Pulau Ambon) untuk menyediakan perahu pengangku yang disebut dengan kora-kora (perahu tradisional Maluku). Armada inilah yang kemudian digunakan untuk melaksanakan pelayaran hongi atau pada masa Belanda disebut ekspedisi hongitochten (Patikayhatu, dkk., 2009: 26 ). Dalam upaya menguasa perdagangan cengkeh, bangsa Eropa melakukan pembatasan penanaman pohon agar pasokan cengkeh dapat dijaga dan harga dapat dipertahankan. Kejayan Kerajan Hoamoal mengalami keruntuhan akibat kekerasan Bangsa Belanda yang ingin memonopoli hasil cengkeh di Kerajaan Hoamoal selama kurang lebih 31 tahun yang juga dibarengi dengan penebangan cengkeh (Ekstirpasi) oleh pasukan Hongitochten Perang yang berlangsung dari tahun 1625 1656 itu dikenal dengan nama perang Hoamoal. Perang tersebut berhasil meluluh lantakan sendi-sendi kehidupan Kerajaan Hoamoal. Paska Perang Hoamoal tepatnya mulai tanggal 6 Maret 1656 kekuasaan kerajaan Luhu (Hoamoal) runtuh, dan banyak penduduk yang direlokasi secara paksa.

Dalam penelitian ini, lokus penelitian adalah di wilayah situs Wayputih, yang terletak di Jazirah Hoamoal, yakni di pesisir selatan Pulau Seram bagian barat, yang menjadi salah satu wilayah dari pemerintahan Kerajaan Hoamoal yang berkembang pada abad 16$17 \mathrm{M}$. Lokasi penelitian, terletak satu garis pantai dengan wilayah pusat pemerintahan Kerajaan Homoal, yakni di pesisir pantai desa Luhu sekarang. Situs Wayputih merupakan sebuah situs pemukiman, yang kini menjadi pemukiman setingkat dusun di wilayah pesisir barat Pulau Seram, pada masa lalu berdasarkan tradisi tutur masyarakat merupakan salah satu pusat penghasil dan pemasok cengkeh dari Kerajaan Islam Hoamoal di Seram Bagian Barat.

Meskipun dalam berbagai sumber sejarah Kerajaan Hoamoal, tidak disebutkan adanya toponim kuno dalam hal ini tempat atau lokasi bernama Wayputih, yang persisnya berada di wilayah pesisir selatan Seram barat, dan berhadapan dengan Kepulauan Lease ( Ambon, Haruku, Nusa Laut) di sebelah selatannya, namun tradisi tutur masyarakat setempat menyebutkan bahwa Wayputih merupakan salah satu desa (negeri) dari keseluruhan negeri wilayah kekuasaan Huamoal berjumlah 99 Negeri. Pada masa kerajaan Homoal, Wayputih adalah salah satu lokasi pusat perkebunan cengkeh Kerajaan Hoamoal pada masa jayanya, yang kemudian dihadiahkan ke wilayah negeri Larike di Pulau Ambon, sebagai hadiah atas bantuannya dalam perang melawan Belanda.

Temuan gerabah, merupakan temuan yang paling dominan dalam penelitian di wilayah-wilayah pemerintahan Kerajaan Hoamoal di sepanjang pesisir selatan Pulau Seram Bagian Barat, termasuk di wilayah situs Wayputih yang menjadi lokus penelitian ini. Gerabah ini merupakan gerabah yang diperkirakan peninggalan masa berkembangnya Kerajaan Islam Hoamoal, wayah Kepulauan Maluku (Maluku dan Maluku Utara) lebih tua dan lebih jauh berkembang sebelum perkembangan niaga pada kerajaan Islam. Dalam konteks tertentu, khususnya untuk temuan gerabah menunjukkan fungsinya dalam tradisi berlanjut dari masa sebelumnya, yakni masa prasejarah. Lokasi Wayputih dalam banyak sumber, disebut sebagai salah satu pusat pemasok cengkeh kerajaan.

Masalah yang penting diangkat dalan konteks perniagaan kerajaan Hoamoal korelasinya dengan gerabah sebagai komoditi, adalah seberapa pentingnya gerabah dibutuhkan oleh masyarakat, sehingga dapat menunjukkan permintaan pasar dalam ha ini kebutuhan masyarakat akan penggunaan gerabah untuk keperluannya. Dalam batasan tertentu, hal ini dapat dijawab melalui analisis kuantitatif serta identifikasi fungsi gerabah dalam masyarakat setempat. Asumsi berkenaan dengan hal ini adalah kuantitas data gerabah dapat menunjukkan intensita perdagangan gerabah di wilayah tersebut.

Mengacu pada hal yang telah disebutkan, maka permasalahan penelitian yang dapat dirumuskan dalam penelitian ini adalah sebagai berikut :

1. Bagaimana bentuk dan fungsi gerabah di wilayah situs Wayputih?

2. Apakah gerabah menjadi salah satu komoditi yang dipertukarkan, serta bagaimana korelasi temuan gerabah dalam konteks perdagangan di wilayah Kerajaan Hoamoal ?

Pada prinsipnya kedua pertanyaan tersebut saling berkaitan untuk menjawa satu tema penting dalam konteks perdagangan lokal dan regional kawasan atau wilayah kerajaan Hoamoal di sepanjang Jazirah Hoamoal, pantai selatan Seram Bagian Barat. Penjelasan-penjelasan berdasarkan data, nantinya saling berkorelasi, mengingat morfologi gerabah dan fungsinya dapat menunjukkan gambaran, bagaimana intensitas 
penggunaan gerabah oleh masyarakat setempat. Sementara kondisi lingkungan situs, dapat memberikan penjelasan tentang daya dukung lingkungan, akses untuk saling berinteraksi dan kemungkinan melihat persebaran gerabah di wilayah situs, yang dapat memberikan gambaran bagaimana gerabah digunakan. Dalam kontek keseluruhan, diharapkan dapat menjelaskan konteks temuan gerabah sebagai komodit niaga dalam perkembangan perdagangan di wilayah kerajaan Hoamoal.

Keberadaan temuan gerabah dalam toponim sejarah, mengindikasikan bahwa keberadaan gerabah merupakan hasil aktifitas masyarakat dalam konteks peradaban sejarah, sehingga bisa disebut sebaga "gerabah sejarah". Istilah ini mengacu pada penyebutan untuk temuan gerabah ata tembikar yang ditengarai dibuat pada periode sejarah, baik periode klasik, Islam maupun 32). Selanjutnya Sant 32). Selanjutnya Santoso Soegondho (1995) menjelaskan, bahwa gerabah masa sejara di Indonesia dapat dibedakan menjadi du kelompok tradisi atau kebudayaan, yaitu tradisi masa klasik atau masa pengaruh HinduBudha dan tradisi masa Islam atau mulai masuknya kebudayaan islam di Indonesia Pada masa manusia mengenal tulisan, gerabah masih terus bertahan, bahkan semakin berkembang, baik jenis, teknologi, maupun fungsinya. Dari awal hingga akhir mas klasik (akhir abad $14 \mathrm{M}$ ). kualitas gerabah pada masa itu sudah semakin meningkat, dengan teknologi pada umumnya pembuatan dengan teknik rodda putar, bahkan sebagian sudah diglasir. Gerabah ini berkembang pada masa berkembangnya penagruh Hindu Budha, sekitar 400 M sampai 1600 M. Ketika pengaruh Islam masuk ke Indonesia sekiatar abad $15 \mathrm{M}$, tradisi pembatan gerabah masih terus berkembang dan penggunaan gerabah juga bertahan. Kualitas gerabah, meskipun tidak banyak berkembang, namun kualitasnya dipertahankan (Soegondho, 1995:33).

Pada masa perkembangan Islam, ditandai dengan berdirinya pusat-pusat pemerintahan
Islam, perdagangan semakin berkembang, dengan saling bertukar komoditi pada proses atau aktifitas niaga yang berlangsung. Salah satu komoditi lokal sebagai bahan pertukaran satu komoditi lokal sebagai bahan pertukaran
dalam proses niaga tersebut, salah satu diantaranya adalah gerabah. Kemungkinan in mengingat hampir di setiap situs pemukiman, gerabah selalu ditemukan, dengan banyak situs diantaranya berasosiasi dengan produkproduk asing, seperti keramik porselen. Data arkeologis memainkan peran penting untuk menambah bahan kajian tentang mekanisme perdagangan lokal seperti kasus pertukaran produk barang metal (logam) pembuat barang tembikar yang yang tidak terekam dalam sumber sejarah (Nayati, 2005:112).

Merujuk pada kasus perdagangan antar pulau di Nusantara, maka di tingkat loka wilayah Kepulauan Maluku, dimana juga terdapat beberapa pusat niaga terkenal, kondisi ini juga kemungkinan telah berlangsung pada masa awal-awal perdagangan dikenal di wilayah ini. Sangat mungkin daerah-daerah kepulauan di Maluku melalaui daerah niaga masing-masing sejak masa awal perdagangan hingga puncaknya yakni masa perkembangan Islam dan Kolonial juga menjalankan mekanisme perdagangan ini. Untuk penjelasan ini, catatan Miksic (1981) sangat berharga untuk dipelajari. Miksic mencatat setidaknya ada 3 pola distribusi komoditi dalam proses perdagangan (pertukaran barang) yakni: pertama: pengambilan langsung (direct acces), yakni antara pihak pengambil bahan dari suatu tempat asal bahan kepada pihak penerima bahan komoditi di tempat tertent untuk menerima barang. Kedua; pertukaran antara dua orang (reciprocity), pertukaran yang terjadi antara pihak penerima dengan pemberi yang dapat berlangsung pada tempa pemberi atau penerima atau juga pada batas antar wilayahnya. Ketiga; pola penyaluran kembali (redistribution), yakni bahan atau komoditi dari pedalaman diterima oleh orang pusat, bisanya raja di ibukota yang kemudian menyalurkannya kembali kepada orang-orang di pesisir. Dengan demikian antara orang pesisir dan pedalaman tidak bertemu langsung. Pola ini menurut Micksic yang banyak terjadi di Indonesia pada masa berkembangnya kerajaan-kerajaan (Miksic, 1981: 10-11)

Bagi wilayah Maluku, studi tentang perdagangan lokal dengan data utama gerabah, untuk melihat distribusinya antara pulau dimana terdapat pusat-pusat niaga, merupakan studi yang penting dalam kaitannya melihat pertukaran produk dan komoditi lokal. Meskipun hampir seluruh pulau memiliki komoditi cengkeh, namun tidak seluruh wilayah mengenal tradisi pembuatan gerabah, sehingga pertukaran komoditi lokal dengan produk lokal seperti gerabah, menjadi sangat mungkin, apalagi jika hal ini dikaitakan dengan upaya penguatan dan pengusaan zona ekonomi yang melibatkan pusat-pusat kekuasaan dan pemerintahan untuk saling berlomba dalam pengusaan niaga dan perekonomian di wilayah-wilayah Dengan penjelasan tersebut, kiranya dapat ditarik sebuah generalisasi, bahwa aktifitas perdagangan pada masa lampau telah melibatkan berbagai pusat niaga yang masing-masing berkompetisi dan saling menukarkan komoditi sesuai dengan kebutuhannnya Demikian, maka di wilayah Kepulauan Maluku khususnya, masing-masing wilayah saling menukarkan produknya sesuai kebutuhan masing-masing antar pulau melalui pusat niaga masingmasing.

\section{METODE}

Pengumpulan data dalam penelitian ini dilakukan melalui survei lapangan, dengan pengambilan sampel gerabah menggunakan metode Purposive sampling, yang pada intinya mengambil sampel berdasarkan tujuan penelitian ( Rangkuti, dkk: 2008: 21). Sehingga pengambilan sampel gerabah dengan mempertimbangkan kualitas dan kuantitas data untuk menjawab permasalahan.

Analisis dilakukan dengan pendekatan ualitatif dan kuantitatif data gerabah. Dalam pendekatan kualititaif, digunakan analisis fisik dan analisis kontekstual.
Analisis kualititaif, meliputi:Analisis Fisik (Morfologi dan fungsional): Analisis ini (morfologi) gerabah yang ditemukan pada suatu situs. Dengan menganalisis morfologi benda diharapkan diperoleh penjelasan tentang fungsi benda dalam suatu situs secara keseluruhan, terdapat himpunan-himpunan benda yang memiliki kesamaan bentuk, sehingga dapat digambarkan bagaimana fungsi benda serta ktifitas dan fungsi sebuah situs. Analisis teknologi : Analisis tehonologi berkaitan dengan pengamatan terhadap bahan dan cara pembuatan suatu temuan arkeologi. Dengan analisis ini akan diperoleh penjelasan tentang kemahiran masyarakat tentang tehnologi pembuatan benda budaya. Analisis Kontekstual : Analisis kontekstual, melihat keletakan benda baik secara horizontal maupun vertikal yang berassosiasi dengan emuan lainnya. Konteks temuan juga melihat assosiasi antara temuan dengan lingkungan situs dan data arkeologi lainnya. Analisis Kuantitatif, meliputi : perbandingan jumlah tiap temuan serta perkembangan jumlah, frekuensi dan prosentase temuan dari hasi survei permukaan tanah. Perbandingan jumlah, frekuensi dan prosesntase ini meliput atribut-atribut benda, sehingga akan diperoleh gambaran menyangkut perkembangan bentuk dan fungsi gerabah dalam situs pemukiman

Pada intinya, analisis fisik bertujuan mengidentifikasi fisik gerabah, baik bahan, bentuk, motif hias dan sebagainya. Sedangkan analisis kuantitatif, menghitung prosentasi dari klasifikasi gerabah berdasarkan jenis, bentuk dan fungsinya. Sementara itu itu analisis kontekstual, adalah melakukan analisis untuk melihat assosiasi data arkeologi dengan data lainnya, lingkungan dan aspek lainnya yang berkaiatan.

Interpretasi data, digunakan pendekatan analogi dan perbandingan dari temuantemuan gerabah lainnya di wilayah kepulauan Maluku yang sudah diketahui persis bentuk dan fungsinya, serta kronologinya. Hasil penelitian gerabah, di wilayah-wilayah lainnya menjadi rujukan dalam melihat perbandingan data gerabah antar wilayah. 


\section{HASIL DAN PEMBAHASAN}

dentifikasi Morfologi dan Fungsi Gerabah

Analisis data arkeologi lebih banyak disandarkan pada temuan gerabah lokal, hal ini karena temuan ini merupakan temuan yang paling dominan dan ditemukan pada seluruh situs yang telah disurvei. Berdasarkan analisis terhadap gerabah baik itu dari aspek morfologi maupun teknologi, menunjukkan situs wayputih telah mengenal penggunaan gerabah dalam jangka waktu lama da berlansgung instensif. Berbagai jenis gerabah menunjukkan banyaknya variasi penggunaan gerabah baik untuk keperluan rumah tangga sehari-hari maupun keperluan yang berhubungan dengant berhubungan denganitual tertentu. Geraba merupakan temuan artefaktual yang paling dominan ditemukan di situs Wayputih, baik di situs terbuka maupun situs gua. Secara garis besar, temuan gerabah tersebut mewakil bentuk wadah dan non wadah, dengan kuantitas yang dominan merupakan bentuk wadah. Dari beberapa pengamatan terhadap atribut gerabah baik bentuk tepian, orientas tepian, dan analisis metrik, diperkirakan gerabah tersebut mewakili bentuk tempayan, periuk, piring, forna (cetakan sagu), mangkuk, wadah yang mempunyai pegangan, tutup, kaki dan bentuk lainnya.

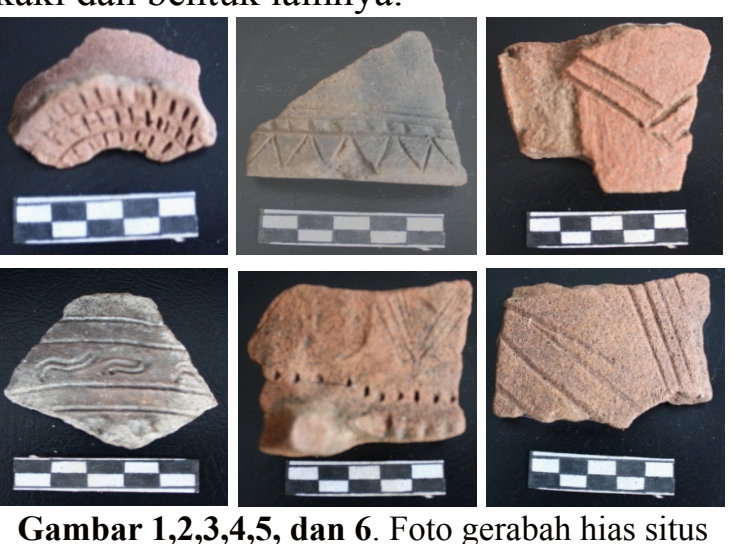

Wayputih.

(Sumber : Dokumen Balai Arkeologi Ambon, 2010)

Dari survey yang dilakukan di kawasan Wayputih meliputi situs terbuka Waytenang ceruk Waytenang II, situs Leang Hamja, Situs Gua Air Murite kecil, situs Air Murite Besar, situs Batu Berdiri, seluruhnya ditemukan

artefak gerabah. Berdasarkan kuantitas data pengambilan sampel data dengan purposive sampling, data gerabah yang paling banyak dikumpulkan adalah dari situs Batu Berdiri, yakni situs yang berada di pesisir pantai, hal ini karena konsentrasi di areal situs ini mewakili gerabah dengan kuantitas terbanyak atau terpadat. Pengamatan di lapangan, di permuk pada situs batu berdiri, terdapat sebaran fragmen gerabah dengan tingkat kepadatan yang sangat tinggi. Hal in menggambarkan bahwa gerabah merupakan perkakas utama yang digunakan masyarakat yang situs tersebut. Letak situs di pesisir pantai, memang lebih me lan kontak perdagangan.

Klasisifikasi terhadap temuan gerabah situs kawasan Wayputih, terdiri dari beberapa jenis frgmen meliputi, badan polos dan hias, tepian polos dan hias, dasar polos dan hias, pegangan dan leher. Berdasarkan analisis metrik pada diameter tepian gerabah baik polos maupun hias, variasi ukuran diameter mulut gerabah antara $12 \mathrm{~cm}-42 \mathrm{~cm}$, yang bisa mewakili bentuk wadah berukuran kecil hingga wadah besar seperti tempayan. Berdasarkan orientasi tepian, pada umumnya terdiri dari tepian terbuka, tegak dan hanya sebagian kecil bentuk tepian tertutup. Pola hias gerabah dapat diamati pada bagian tepian, badan dan dasar. Pada bagian badan jenis motif hias diantaranya motif garis, motif lekukan, sulur, geometris. Sedangkan pada bagian tepian pada umumnya berupa mootif hias garis, baik garis lurus maupun garis segitiga yang bersambung-sambungan, selain itu terdapat motif tepian bergelombang, dengan tehnik tekan maupun iris. Untuk fragmen badan, terdiri dari badan polos, badan hias, berslip merah, dan bagian badan berupam hitam. Bagian badan memiliki ketebalan antara $2-12 \mathrm{~mm}$. Beberapa bagian badan polos terdapat bekas pembakaran berwarna hitam, yang menandakan bahwa gerabah tersebut digunakan sebagai wadah untuk memasak. Untuk kategori gerabah ini, ditemukan di situs terbuka. Sedangkan di situs gua, pada umumnya tidak mencirikan penggunaan untuk memasak. Di Situs Gua Air Mmurite besar, misalnya terdapat bagian badan hias yang berwarna hitam, namun kemungkinan warna hitam disebabkan oleh pembakaran yang tidak sempurna, bukan karena bekas pemakaian untuk memasak.

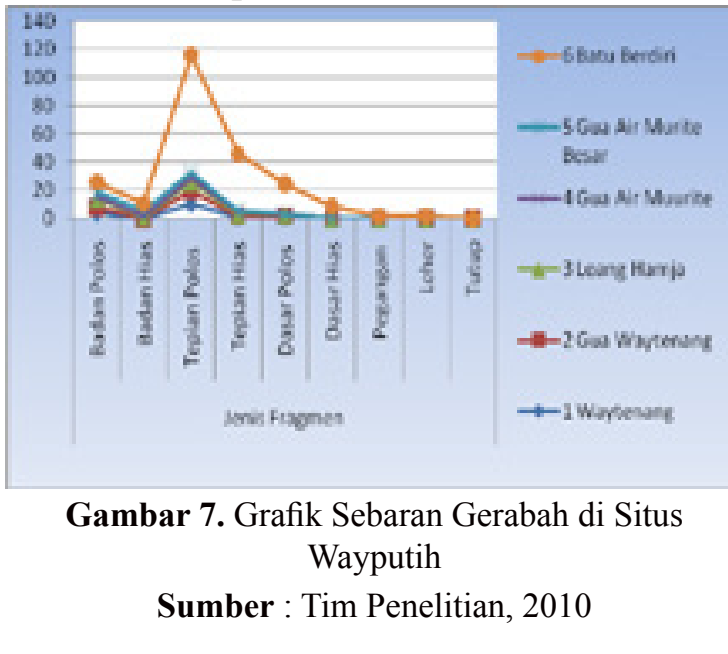

Sementara jenis wadah, pada umumnya polos banyak ditemukan di situs terbuka yakni Situs Waytenang dan Batu Berdiri. Variasi wadah, terdiri dari wadah yang memiliki pegangan dan beberapa di antara kemungkinan memiliki tutup. Jenis wadah, terutama di situs gua penguburan, pada umumnya wadah berdiameter besar. Bagian dasar terdiri dari beberapa jenis, yakni dasar membu Berdasarkan jejak yang ditinggalkan, terdapat beberapa ciri pembuatan gerabah, antara lain tehnik roda putar, dengan ciri-ciri garis-garis striasi pada permukaan gerabah teknik buatan tangan, handmade tatap pelandas. Sementara itu, teknik tatap pe permukaan-permukaan gerabah yang tidak merata atau bergelombang.

Selain gerabah juga ditemukan keramik asing dalam jumlah yang minim, hal ini menunjukkan interaksi dengan pihak luar kurang intensif. Meski demikian, hal ini masih perlu diuji lagi, mengingat, kawasan Wayputih berada di peisisir pantai, sehingga secara geografis, relatif mudah berinteraksi dengan pihak luar. Keramik asing merupakan salah satu temuan yang cukup penting, namun pada situs ini temuan keramik asing sangat

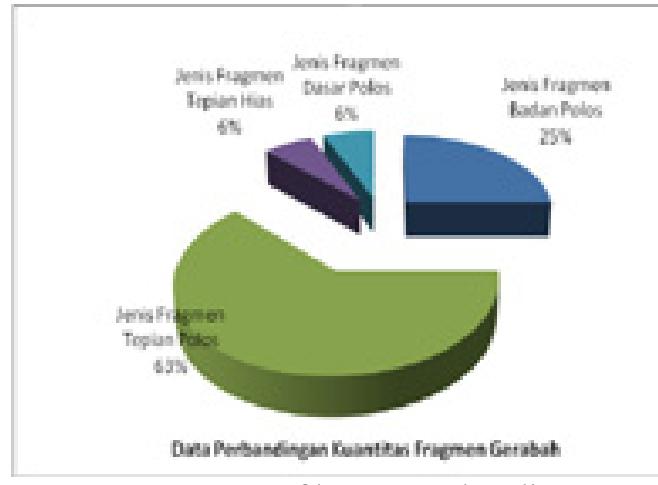

Gambar 8. Grafik Data Perbandingan Jenis Fragmen Gerabah di Situs Sumber : Tim Penelitian, 2010

minim. Pada umumnya keramik lebih banyak ditemukan di situs-situs terbuka, di atas permukaan tanah. Fragmen tulang, ditemukan pada umumnya di dalam gua ata ceruk, menunjukkan rata-rata tengkorak orang dewasa, yang ditemukan secara berkelompok dalam jumlah yang banyak. Hal ini menandakan bahwa gua atau ceruk, difungsikan dalam kaitannya tradis penguburan.

Penjelasan menyangkut analisis lingkungan situs diamati berdasarkan lokasi, ciri-ciri bentuk lahan, jenis situs, yakni menunjukkan apakah situs gua atau situs pemukiman terbuka (open site) dan peninggalan arkeologis. Berdasarkan pengamatan dan analisis terhadap lingkungan sekitar situs, maka dapat memberikan gambaran mengenai aktifitas masyarakat dalam pemanfaatan situs dan lingkungan sekitar.

Berdasarkan pola pemanfaatan lahan yang dapat diamati, maka situs-situs itu berada pada wilayah bukit (lereng perbukitan) dan pesisir pantai. Meski demikian keseluruhan situs berada relatif dekat dengan sumber air Untuk situs-situs gua yang pada umumnya digunakan sebagai situs penguburan berada pada lereng bukit dengan ketinggian antara 300-500 mdpl. Pemilihan situs gua sebagai lokasi penguburan pada ketinggian itu, mungkin bertujuan selain lokasi yang dianggap relatif aman, kemungkinan ada makna-makna religius magis tertentu, sehingga lokasi gua- 
gua pada ketinggian itulah yang digunakan sebagai lokasi penguburan. Analisis ini berdasarkan pada pengamatan lapangan, bahwa terdapat beberapa gua di pesisir panta yang lokasinya lebih rendah tidak digunakan sebagai lokasi penguburan.

Tabel 1. Lokasi Temuan Sebaran Gerabah

\begin{tabular}{|l|l|l|l|l|}
\hline Situs & Jenis Situs & $\begin{array}{l}\text { Tinggi } \\
\text { (Mdpl) }\end{array}$ & $\begin{array}{l}\text { Bentuk } \\
\text { Lahan }\end{array}$ & $\begin{array}{l}\text { Jenis } \\
\text { Temuan } \\
\text { Arkeologis }\end{array}$ \\
\hline $\begin{array}{l}\text { Situs Leang } \\
\text { Waytenang }\end{array}$ & $\begin{array}{l}\text { Situs Gua, berjarak 1 } \\
\text { km dr sumber air }\end{array}$ & $500 \mathrm{mdpl}$ & $\begin{array}{l}\text { Daerah lereng } \\
\text { perbukitan }\end{array}$ & $\begin{array}{l}\text { Gerabah, Fragmen } \\
\text { Tulang tengkorak }\end{array}$ \\
\hline $\begin{array}{l}\text { Situs waytenang } \\
\text { II }\end{array}$ & $\begin{array}{l}\text { Situs terbuka, lereng } \\
\text { bukit }\end{array}$ & $500 \mathrm{mdpl}$ & $\begin{array}{l}\text { di daerah lereng } \\
\text { perbukitan }\end{array}$ & $\begin{array}{l}\text { Gerabah (berbagai } \\
\text { varias gerabah, } \\
\text { polos, hias, tebal dan } \\
\text { tipis) }\end{array}$ \\
\hline $\begin{array}{l}\text { Situs Leang } \\
\text { Hamjah }\end{array}$ & Situs Gua & $300 \mathrm{mdpl}$ & Lereng perbukitan & $\begin{array}{l}\text { Gerabah (dominan } \\
\text { tembikar hias dan } \\
\text { tipis) }\end{array}$ \\
\hline $\begin{array}{l}\text { Situs Gua Air } \\
\text { Murite }\end{array}$ & Situs Gua & $200 \mathrm{mdpl}$ & Perbukitan & $\begin{array}{l}\text { Gerabah (dominan } \\
\text { tembikar hias dan } \\
\text { tipis) }\end{array}$ \\
\hline $\begin{array}{l}\text { Situs Gua Air } \\
\text { Murite Besar }\end{array}$ & Situs Gua & $200 \mathrm{mdpl}$ & Perbukitan & $\begin{array}{l}\text { Gerabah, tulang } \\
\text { tengkorak }\end{array}$ \\
\hline $\begin{array}{l}\text { Situs Gua Air } \\
\text { Babunyi }\end{array}$ & Situs Gua & $350 \mathrm{mdpl}$ & Perbukitan & $\begin{array}{l}\text { Gerabah, Tulang } \\
\text { tengkorak }\end{array}$ \\
\hline Situs Batu Berdiri & $\begin{array}{l}\text { Open site, pesisir } \\
\text { pantai }\end{array}$ & $5 \mathrm{mdpl}$ & Pesisir pantai & $\begin{array}{l}\text { Gerabah (temuan } \\
\text { dengan konsentasi } \\
\text { sangat padat) }\end{array}$ \\
\hline
\end{tabular}

Sumber : Tim Penelitian, 2010

Berdasarkan analisis bentuk dan motif hias serta keletakannya pada situs, menunjukkan bahwa pada umumnya merupakan jenis wadah. Namun demikian, jenis wadah gerabah yang ditemukan di situs gua, perlu penelitian lebih lanjut tentang fungsi gerabah, apakah ada kemungkinan menjadi salah satu materi dalam tradisi penguburan Wengingat di wilayah Wayputih, jika merujuk sumber-sumber lisan, merupakan masyarakt komunitas Islam, bagian dari wilayah kerajaan Islam Hoamoal. Namun kemungkinan pula, keberadaan gerabah dalam gua, bisa sesuatu yang kebetulan. Pada masa penguasaan VOC, dimana ekspedisi dimana ekspedisi hongitocten y memusnahkan seluruh perkebunan cengkeh di

wilayah Hoamoal, di situs Wayputih, sebagai salah satu sentra perkebunan cengkeh, telah terjadi perang antara masyarakat setempa untuk mempertahankan cengkehnya dengan tentara-tentara VOC, sehingga temuan kerangka dalam gua beserta pecahan-pecahan (a) gerabah, kemungkinan sesuatu yang kebetulan. Namun bisa pula, tradis pengubuaran dalam gua, adalah tradisi yang masih berlanjut bagi masyarakat muslim Wayputih yang baru saja mengkonversi Islam pada masa awal Islamisasi di wilayah tersebut. Tampaknya dominasi temuan gerabah hias di situs-situs gua, yang berassosiassi dengan tulang tengkorak, seperti situs Gua Air Babunyi, Situs Gua Air Murite, Situs Gua Leang hamja, dan Situs Ceruk Waytenang, bukanlah gerabah untuk keperluan seharihari, namun lebih menunjukkan gerabah dalam makna tradisi magis religius, sebagai barang serta untuk penguburan dalam gua Tampaknya tradisi penguburan dalam gua, adalah tradisi yang masih berlanjut, meskipun masyarakat Wayputih sudah mengkonversi Islam. Mungkin tradisi ini masih berlanjut ketika awal persentuhan masyarakat dengan religi Islam.

Secara kuantitas, gerabah paling banyak ditemukan di situs yang terletak di pesisir pantai. Kemungkinan lokasi ini sengaja dipilih sebagai lokasi hunian yang difungsikan dalam jangka angka waktu yang lama dan lebih intensif. Selain itu secara umum, situs wayputih terdiri dari lingkungan pantai dan perbukitan, dengan lokasi pemukiman penduduk dipusatkan di pesisir pantai dengan bentuk linier mengikuti garis pantai. Kondisi lingkungan yang demikian, sangat mudah untuk berinteraksi dengan masy dengan masyarakat luar, sehingga, dalam konteks ini akses perdagangan dengan pihak luar lebih mudah.

Kemungkinan, wilayah dengan lokasi di pesisir pantai dan di wilayah landai dipilih masyarakat sebagai lokasi permukiman dengan aktivitas okupasi yang lebih intensif. Meskipun demikian, daerah permukiman di wilayah kelerengan seperti di situs Waytenang pada ketinggian 300 mdpl juga dipilih sebagai lokasi hunian. Namun tampaknya berdasarkan perbandingan kuantitas dan variasi tipologi gerabah, situs pesisir pantai yakni situs Batu Berdiri lebih menguntungkan dibandingkan lokasi di kelerengan bukit.

\section{Gerabah sebagai Komoditi Perdagangan} Lokal

Merujuk pada kasus perdagangan antar pulau di Nusantara, maka di tingkat lokal wilayah Kepulauan Maluku, dimana juga terdapat beberapa pusat niaga terkenal, kondisi ini juga kemungkinan telah berlangsung pada masa awal-awal perdagangan dikenal di wilayah ini. Sangat mungkin daerahdaerah kepulauan di Maluku melalui daerah niaga masing-masing sejak masa awal perdagangan hingga puncaknya yakni masa perkembangan Islam dan Kolonial juga menjalankan mekanisme perdagangan ini. Hingga saat ini aktifitas perdagangan lokal untuk kebutuhan lokal dan regional di wilayah Maluku masih berlangsung. Berdasarkan pengamatan lapangan dan wawancara dengan masyarakat setempat, mereka menggunakan kapal layar membawa komoditi lokal berup keladi untuk dijualbelikan hingga ke wilayah Sulawesi Tenggara dan Kabupaten Bangga di Sulawesi Tengah bagian timur. Selanjutnya dari daerah setempat membawa komoditi untuk kebutuhan di wilayah Maluku. Proses seperti ini telah berlangsung sejak masa kerajaan Hoamoal pada abad ke-16 di Seram dan masih bertahan hingga kini.

Meskipun temuan gerabah pad umumnya menunjukkan teknologi yang lebih maju, namun bukan berarti sezaman dengan penggunaan keramik, mengingat keramik sing yang ditemukan menunjukkan ciri kronologi yang relatif muda, yakni Ming (1617 M), Qing (17-18 M) serta Eropa (18-19 M). Temuan gerabah mengindikasikan adanya kegiatan ekonomi masyarakat setempat dengan daerah luar. Melihat motif hiasnya yang menunjukkan khas Maluku, dapa diduga gerabah itu didatangkan melalui proses perdagangan lokal antar daerah atau pulau-pulau di wilayah Kepulauan Maluku. Kemungkinan daerah Saparua ataupun di Maluku Utara, serta Kepulauan Banda merupakan daerah asal gerabah, namu demikian hal ini perlu lebih dipastikan lagi melalui studi khusus untuk mengidentifikasi teknologi pembuatan gerabah di kedua daerah asal tersebut. Studi khusus ini dilakukan untuk mengetahui gaya (style) dan kekhasan setiap daerah asal pembuatan gerabah. Namun berdasarkan pengamatan empiris, dari data gerabah, tampak terdapat beberapa gerabah yang memiliki ciri pembuatan Gerabah dari Saparua. Pulau Saparua adalah pulau terdekat dari situs Wayputih, dimana Desa Ouw di Saparua adalah wilayah yang masih mempertahankan tradisi pembuatan gerabah hingga sekarang. Beberapa lainnya juga menunjukkan ciri gerabah Pulau Mare di Maluku Utara. Pengamatan empiris membandingkan temuan data gerabah dengan gerabah Mare seperti yang diperlihatkan dalam tulisan Mahirta (2000), yakni terutama dari motif hiasnya. Selain itu, terdapat pula ciri- 
ciri gerabah yang memiliki kesamaan dengan gerabah Kepulauan Banda, sebagaimana yang telah digambarkan dalam disertasi Lape (2000) dan Chung Ching Shiung (2011).

Berdasarkan tradisi tutur ataupun pengakuan masyarakat komunitas muslin yang bermukim di wilayah Wayputih sebagian besar merupakan keturunan dari leluhur mereka yang berasald ari Maluku Utara. Dalam sejarah telah banyak dijelaskan, bahwa Ternate, merupakan pusat kekuasaa Islam di Maluku Utara yang melakukan ekspansi dan menyebarkan Islam di wilayah Kerajaan Hoamoal, serta kerajaan Hoamoa sendiri dalam beberapa sumber merupakan wilayah konfederasi dari Ternate. Temuan gerabah yang memilki ciri asal dari tradis pembuatan gerabah di Maluku Utara (Pula Mare), bisa mempertegas hubungan tersebut. Sementara ciri gerabah dari wilayah atau pulau lain, seperti Banda dan Saparua, menunjukkan bahwa gerabah merupakan komoditi perdagangan regional, yang menghubungkan pulau-pulau di kawasan kepulauan Maluku. Selain itu dapat didug masyarakat di Jazirah Hoamoal, sejak dulu telah mengenal perdagangan dengan pihak asing. Adanya keramik asing dapat diduga an hasil barter antara komoditi lokal daerah setempat dengan pihak asing atau pihak pedagang lokal di pesisir yang mendistribusikan keramik asing ke pedalaman ataupun atau perdagangan dengan mata uang. Dugaan ini mengingat tradisi perdagangan antar pulau dengan kapal tradisional bagi masyarakat Wayputih hingga sekarang masih berlangsung.

Dalam soal komoditi perdagangan di Maluku, Lape (2000) menemukan bahwa porselen dan gerabah adalah indikator yang baik dari perdagangan dan aksesibilitas kekayaan. Namun dia melihat kecenderungan peningkatan barang dari luar (komoditi asing) lambat laun menggeser perkakas tradisiona di wilayah-wilayah pemukiman Islam. Mesk demikian dalam kasus Wayputih, tampak bahwa gerabah adalah temuan domina dibanding dengan keramik asing, ini bukt bahwa perdagangan lokal di wilayah tersebut, dan produk-produk lokal, seperti gerabah lebih dominan. Mungkin dalam konteks ini, Wayputih, meskipun sebagai salah satu pusat cengkeh Kerajaan Hoamoal, namun bukanlah pihak yang berhubungan langsung dengan pedagang asing. Selain itu masyarakat, lebih sering menggunakan produk lokal untuk kebutuhan rumah tangga, karena pemasok barang yang langsung berhubungan dengan Wayputih adalah pedagang-pedagang loka dari wilayah Maluku sendiri.

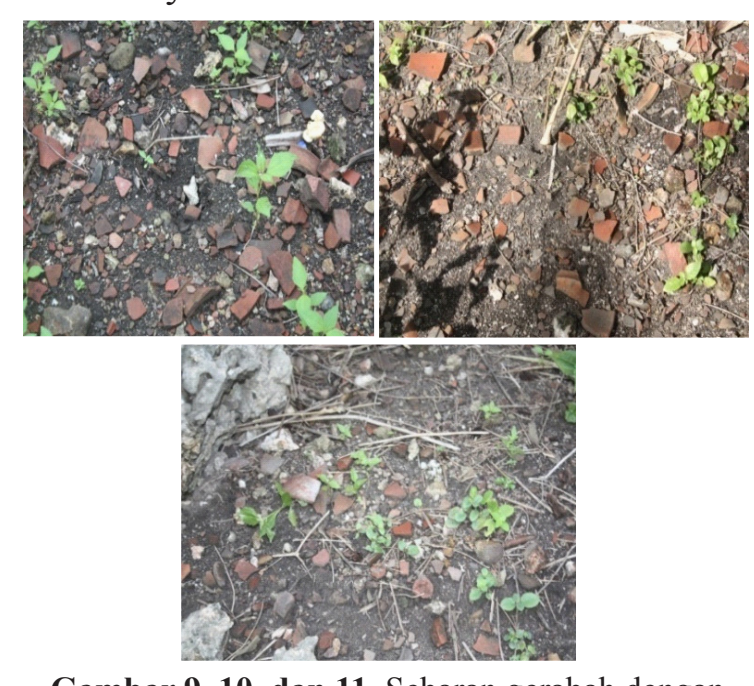

Gambar 9, 10, dan 11. Sebaran gerabah deng

konsentrasi yang sangat padat di pesisir pantai situs Wayputih

(Sumber: Dokumen Balai Arkeologi Ambon)

Pada kasus ini dapat ditelusuri kontak dagang Wayputih dengan masyarakat di luar pulau dalam kawasan kepulauan Maluku. Sebagai contoh, ditemukannya gerabah yang tipologinya sama dengan Gerabah Mare misalnya, membuktikan bahwa Wayputih menjalin kontak dagang dengan wilayah Maluku Utara, meskipun kontak langsungnya melalui Ternate, sebagai pihak yang pernah menguasai wilayah Kerajaan Hoamoal. Di bahwa tradisi pembuatan tembikar di Pulau Mare, mungkin telah berlangsung sejak sekitar 1.000 BP. Analisis kimia memperlihatkan komposisi bahan tembika buatan, motif gelombang, spiral dan unsur"S" pada bagian bibir gerabah yang datar, maupun bagian dalam tepian gerabah, adalah ciri khas Mare (Mahirta, 2000:129). Ratusan tahun kemudian, tembikar Mare mengalami perubahan, dimana ada kecenderungan dengan tipe gerabah merah bakar

Tampaknya gerabah merah bakar di Mare merupakan perubahan yang baru-baru saja terjadi. Tipe merah bakar, tampaknya mendukung penjelasan bahwa tembikar merah bakar adalah produk lokal. Teknik pembakaran ini mungkin timbul karena kontak asing. Dari ciri-ciri gerabah ini, ditemukan pula di wilayah Wayputih. Selain itu ditemukan pula ciri-ciri gerabah Ouw dan Kepulauan Banda. Ada pendapat ahli, yang mengemukakan, bahwa temuan gerabah berciri tradisi gerabah Ouw, menunjukkan kronologi hunian situs tersebut, masih baru. Spriggs (1990), mengatakan prosentase gerabah Ouw menunjukkan perkiraan situs pemukiman dalam proporsi terbalik. Artinya semakin tua humian situs, semakin kecil prosentase temuan gerabah Ouw, sebaliknya, semakin muda hunian situs, maka semakin besar prosentase temuan gerabah Ouw. Tampaknya dalam kasus situs Wayputih masih perlu ditinjau kembali, mengingat intensitas temuan gerabah dari berbagai daerah masih harus diteliti kembali prosentasi kuantitasnya. Namun jika merujuk pada perkembangan kerajaan Hoamoal pada abad ke-16 dan ke-17 M, mungkin pendapat itu benar dan sesuai untuk kronologi situs Wayputih. Meski demikian, adanya gerabah dari berbagai lokasi, menunjukkan intensitas pertemuan yang intensif dengan wilayah luar pulau dalam relasi perdagangan lokal.

Sejumlah situs, ditemukan gerabah di permukaan tanah beberapa diantaranya walaupun dengan jumlah minim, ditemukan berasssiasi dengan keramik asing, demikian pula di situs Wayputih. Sprigs (1990) dan Stark (1996) mengatakan assosiasi antara gerabah dan keramik asing, memberikan assumsi bahwa persebaran gerabah mungkin telah terbentuk dalam beberapa ratus tahun terakhir. Namun minimnya situs-situs kuno, menyebabkan keraguan, apakah produksi gerabah telah ada di Maluku Tengah sebelum adanya kedatangan orang Jawa pada abad ke-12 M (Ellen dan Glover, 1974). Namun, mengingat bahwa produksi gerabah ada dari sekitar $3.400-4.000$ BP di Maluku Utara,Sulawesi, dan Timor, maka tidak mungkin Maluku Tengah merupakan zona bebas tembikar sampai 800 tahun yang lalu (Ellen dan Glover 1974; Latinis dan Stark 2003). Satu penjelasan untuk anomal ini mungkin bahwa ada kelimpahan bahan organik seperti bambu, daun, kulit kayu, dan batok kelapa yang dapa digunakan sebagai peralatan alternatif pengganti gerabah, bahkan diperkuat dengan adanya fakta beberapa suku pedalaman di Maluku, yang tidak pernah menggunakan gerabah (Latinis 1999: 454)

Para ahli mengesankan bahwa pengenalan gerabah di Maluku Tenga sangat lambat. Meski demikian di Desa Ouw, Pulau Saparua, Maluku Tengah, penggunaan gerabah sangat berkembang bahkan tradisi pembuatan gerabah masih bertahan hingga kini. Ellen dan Glover(1974) melihat bahwa desa-desa penghasil gerabah, cenderung terletak di pulau-pulau kecil. Spriggs (1990), sebaliknya, mengusulkan bahwa tradisi leluhur pembuatan tembikar di Maluku Tengah semestinya datang dari Pulau Seram, mengingat tembikar yang ada saat ini diproduksi di pulau besar. Hal in didukung oleh penyelidikan Bartel (1977: 109) di Hutumuri dan Haruku, katanya teknologi gerabah berasal dari Pulau Seram. Sejauh ini, hipotesis tentang produksi gerabah dari pulau-pulau kecil ataukah dari Pulau Seram, keduanya masih tentatif, dan sulit untuk menguji atau mengevaluasi kebenaran keduanya (Shiung, 2011 : 103-105).

Dalam konteks temuan gerabah di situs Wayputih, yang dapat dikatakan melimpah, asal muasal produksi gerabah dari beberapa wilayah yang sudah disebutkan di atas, tampaknya lebih sesuai. Assumsi awal, bahwa gerabah Wayputih adalah gerabah perdagangan, yakni komoditi yang berasa dari luar wilayah, cukup meyakinkan, 
karena pertama : kondisi lingkungan yang didominasi oleh lapisan tanah merah dan batuan karst, tidak memungkinkan untuk pencarian bahan baku gerabah. Kedua tidak ada tradisi tutur yang mengatakan bahwa masyarakat di situs Wayputih adalah penghasil gerabah. Ketiga: pada masyaraka sekarang, tidak ada penggunaan gerabah yang intensif untuk keperluan sehari-hari Keempat; gerabah-gerabah yang ditemukan banyak diantara memiliki ciri yang sama dengan gerabah dari luar, baik Mare (Maluku Utara), Desa Ouw (Pulau Saparua) maupun Banda. Sedangkan apakah terdapat gerabah yang berasal dari Pulau Seram sendiri, masih perlu diteliti kembali, beberapa petunjuk tentang itu tampaknya dapat diselidik bahwa diantaranya terdapat motif hias yang khas pulau Seram, karena dari berbaga penelitian, motif gerabah ini hampir selalu ditemukan di situs-situs di wilayah Pulau Seram, yakni motif hias titik-titik, atau bintikbintik, tampak seperti segitiga tumpal, yang digoreskan atau dengan cara tusuk dengan alat tertentu semacam lidi, pada permukaan dasar gerabah bagian dalam dan diletakkan melingkar dan berkelompk. Biasanya di bagian tengah, dihias lagi seperti motif hias flora atau geometeris.

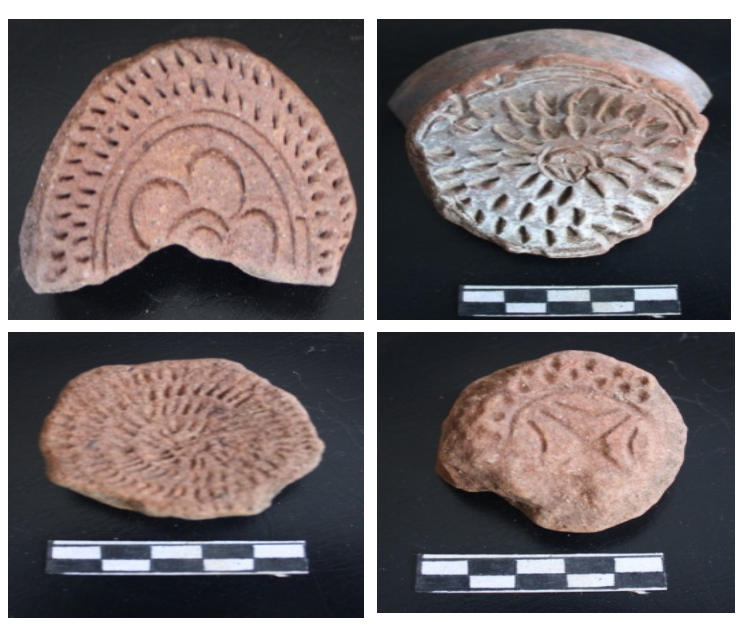

Gambar 12, 13, 14, dan 15. Motof Hias gerabah yang kemungkinan menunjukkan gerabah khas Pula Seram, mengingat jenis gerabah ini hampir selalu ditemui di situs-situs pemukiman di Pulau Seram.
(Sumber : Dokumen Balai Arkeologi Ambon, 2010)

\section{PENUTUP}

Situs pemukiman Wayputih di pesisir pantai selatan Pulau Seram bagian Barat, merupakan sebuah situs yang penting dalam konteks perkembangan Kerajaan Hoamoal, terutama berkaitan dengan perkembangan perdagangan di wilayah tersebut. Temuan gerabah lokal dalam kuantitas yang melimpah, membuktikan adanya intensitas masyarakat yang bermukim dan menggunakan perkakasa gerabah sebagai kebutuhan sehari-hari. D samping itu situs Wayputih sebagai salah satu pusat pemasok cengkeh bagi Kerajaan Hoamoal, merupakan wilayah yang memiliki peran penting dalam menunjang gerak dan relasi niaga Kerajaan Hoamoal yang terletak di pesisir selatan Pulau Seram bagian Barat dengan wilayah-wilayah niaga lainnya Tampaknya situs Wayputih juga memiliki peran dalam relasi perdagangan antar pulau dalam lokalitas kawasan Kepulauan Maluku. Temuan gerabah di situs Wayputih, yang memiliki ciri gerabah Pulau Saparua di Maluku Tengah, Pulau Mare di Maluku Utara, Pulau Banda membuktikan bahwa wilayah-wilayah tersebut saling menjalin kontak niaga.

Pulau Seram, tepatnya di Kerajaan Hoamoal, sebagai salah satu penghasil rempah-rempah cengkeh, dan menjadi bagian dari wilayah ekspansi kekuasaan islam Ternate, menjadi salah satu basis kekuatan ekonomi kesultanan Ternate, sehingga relas perdagangan lokal dengan wilayah-wilayah pusat niaga lainnya merupakan proses yang terbangun dalam membangun zona ekonomi dan perdagangan lokal wilayah keuasaan Islam, bahkan hubungannya dengan persaingan pihak Kerajaan lokal dengan Kolonial, terutama Belanda. Gerabah, sebagai alat rumah tangga sehari-hari memberikan bukti bahwa komoditi lokal melalaui proses perdagangan lokal saling dipertukarkan. Pulau Seram, memalui Kerajaan Hoamoal, salah satunya, yang berperan pula sebagai pemasok cengkeh, memungkinkan saling menjalin relasi perdagangan dengan wilayahwilayah lainnya dalam kawasan Kepulauan Maluku.

\section{DAFTAR PUSTAKA}

Bartels, Dieter. 1977. Guarding the Invisible Mountain: Inter-village Alliances, Religious Syncretism and Ethnic Identity among Ambonese Christians and Moslems in the Moluccas. Ph.D. Dissertation.

Ellen, Roy F., and I. C. Glover. 1974. Pottery Manufacture and Trade in the Central Moluccas, Indonesia:

Fadillah, Moh Ali dan Surachman, Heddy. 2000. Tembikar Perdagangan di Pesisir Barat Kalimantan; Kajian Awal Aspek 04/2000. Banjar Baru: Balai Arkeologi 04/2000. Banjar
Banjarmasin.

Mahirta, 2000. The Development of the Mare Pottery Tradition in the Northern Moluccas. Bulletin of the Indo-Pacific Prehistory Association 20(4):124-132.

Miksic, John N, 1981. Perkembangan Teknologi, Pola Ekonomi dan Penafsiran Data Arkeologi di Indonesia. Majalah rkeologi. Tahun IV No 1-2. Lembaga Arkeologi. Fakultas Sastra Universitas Arkeologi.
Indonesia.

Nayati, Widya. 2005. Social Dynamics and Local Trading Pattern in the Bantaeng Region, South Sulawesi (Indonesia) circa 17th century. A Thesis Submitted For The Degree Of Doctor Of Philosophy The Southeast Asian Studies Programme. National University Of Singapore.

Lape, Peter. 2000. Contact and Conflict in the Banda Islands, Eastern Indonesia,11th17th Centuries. Ph.D Dissertation, Department of Anthropology, Brown University.
Latinis, Kyle. 1999. Subsistence System Diversification in Southeast Asia and the Pacific: Where Does Maluku Fit. Ph.D Dissertation, Anthropology, University of Hawaii.

Latinis, Kyle, and Ken Stark. 2003. Roasted Dirt: Assessing Earthenware Assemblage from Sites in Central Maluku, Indonesia. In Earthenware in Southeast Asia. J.N Miksic, ed. Pp. 103-135. Singapore: Singapore University Press.

Leirissa R.Z. 1973. Kebijaksanaan VOC untuk mendapatkan Moniopoli Perdagangan Cengkeh di Maluku Tengah antara Tahu 1615 dan 1652, dalam Bunga Rampai Sejarah Maluku (1), Jakarta: Lembag Penelitian Daerah Maluku.

Leirissa, Ricard Z. 2001. Jalur Sutera: Integrasi Laut-Darat dan Ternate sebagai Bandar Jalur Sutera. Dalam M.J. Abdulrahman, et.al. Ternate: Bandar Jalur Sutera, Ternate: LinTas (Lembaga Informasi dan Transformasi Sosial).

Patikayhatu, dkk., 2009. Sejarah Negeri dan Desa di Kota Ambon. Ambon: Dinas Pariwisata, Kebudayaan, Pemuda dan Olahraga.

Rangkuti, Nurhadi, dkk. 2008. Buku Panduan Analisis Keramik. Jakarta: Pusat Penelitian dan Pengembangan Arkeologi Nasional.

Ricklefs, M.C. 2008. Sejarah Indonesia Modern 1200-2004. Jakarta: PT Serambi Ilmu Semesta.

Soegondho, Santoso. 1995. Tradisi Gerabah di Indonesia. Dari Masa Prasejarah Hingga Masa Kini. Himpunan Keramik Indonesia. Jakarta: PT. Dian Rakyat

Spriggs, M. 1990. Archaeological and Ethnoarchaeological Research in Maluku 1975 Unfinished Story. Cakalele 1(1/2):47-60.

Stark, Kenneth J. 1996. Alternative Rainfores Economies of Maluku, Indonesia: A Reply to the "Wild Yam Hypothesis" from the Archaeological Record. Ph.D Dissertation, Anthropology, University of Hawaii. 
Shiung, Chung Ching. 2011. The Implications of Social, Cultural, Economic, and Political Interactions for Ceramic Evolution on the Banda Islands, Maluku Province, Indonesia. Dissertation, Ph.D Archaeology.Washington University

Tim Penelitian. 2010. Penelitian Arkeologi Permukiman di Kawasan Wayputih, Kecamatan Leihitu, Kabupaten Maluku Tengah. Ambon: Balai Arkeologi Ambon. Tidak terbit 